\title{
Contention in the age of austerity in Europe: the emergence of new alternatives?
}

David Bailey (University of Birmingham)

Louisa Parks (University of Lincoln)

Corresponding author: David Bailey d.j.bailey@bham.ac.uk

The series of economic crises that began in 2007 - but which took a specific form in Europe from 2010 onwards - marked the onset of the so-called 'age of austerity'. Whilst the 'silver age of permanent austerity' had already been declared prior to 2008 (Ferrera 2008), events since 2010 have brought about a sense of the further consolidation of austerity and neoliberalism, sometimes to an overwhelming degree (Blyth 2013; Stanley 2014). Indeed, on occasion it feels as if understanding the imposition and impact of austerity is both necessary and sufficient to understanding the present. This sense of being overwhelmed by austerity, however, needs at the very least to be accompanied by a consideration of the alternatives to austerity and neoliberalism that are continually proposed, advanced and which challenge and contest the seemingly prevalent austerity agenda (Huke et al, 2015). If we fail to study, highlight, explore and examine alternatives that are being created in the present, we risk denying through our scholarship what could otherwise be sources of inspiration and hope. The crisis has not only closed down opportunities, but also witnessed a wave of new forms of contestation, resistance, and the construction (or the attempt to construct) a range of alternatives that counter an otherwise gloomy scenario where neoliberalism is both victorious and endless. It is to these avenues for change and hope that we turn our attention in this special issue.

Our intention is to highlight both ways in which austerity might be opposed, and alternatives to a neoliberal agenda that might be realised in the present. In this sense we seek to go beyond the more common focus within the comparative politics and comparative political economy literature on how austerity and neoliberalism have been consolidated. Whilst this consolidation may or may not have happened (and the articles do not necessarily agree on this point), the contributions to the special issue do agree that more progressive, egalitarian, alternatives can and do exist, albeit with differences between the authors over the degree to which we can hope for them to be realised, and how. It is this debate, therefore, which we seek to further in the current special issue, and which we fear might sometimes be obscured as a result of an otherwise predominant focus on austerity.

Of course, this raises the question of what we mean when we refer to contestation, resistance and alternatives. We have tried to adopt as broad a conception of contestation as we have been able. From the so-called 'imperceptible' forms of everyday dissent and rebellion that James C. Scott once called 'hidden transcripts' (the modern version of which might be internet memes lampooning the elite) (Scott, 1990; Lonkila forthcoming), through the more visible and 'standard' forms of resistance, including protests, demonstrations, strikes, and occupations, to the articulation of what are often considered more 'autonomous' alternatives, including expressions of mutual aid, cooperatives, and attempts to instantiate modes of cooperation that reject the hierarchies that oftentimes seem to embody modern life (Wigger 2016). Whilst this includes actions that take place outside of the sphere of formal politics, we also focus on the way in which alternatives to neoliberalism and austerity are being promoted within the formal politics of both the nation-state and the European Union. These are far from being disconnected. Indeed, the concrete alternatives considered within formal politics can 
often be directly attributed to acts of contestation that have arisen in response to the austerity agenda.

Developing alternatives in the context of the so-called 'age of austerity' also requires us to consider what exactly we mean by the term 'austerity', as well as why it might prompt alternatives to emerge. Konzelman (2014) defines austerity as a process whereby public spending is reduced and/or tax revenues are increased, often in an attempt to achieve an improvement in the fiscal health of the government, which is itself perceived to be economically necessary. Austerity might be considered, therefore, the attempt to reduce or remove the provision by the state of resources that supplement those allocated through market exchange. This includes attempts to increase the costs to the taxpayer (normally in a regressive way) of funding those supplementary resources. Whilst many consider austerity and neoliberalism to be synonymous, moreover, it might be more accurate to consider austerity to be a part of a broader neoliberal agenda. Neoliberalism in this sense also includes an evergreater emphasis upon the market, a process of financialisation, the dismantling of institutions representing the 'left' or 'labour', a greater disciplinary role for the state, and a consistent attempt to place substantial limits on the range of political outcomes considered permissible within the institutions of representative democracy (on which, see Harvey 2005; Peck et al. 2012; Wacquant 2010).

The alternatives that we consider, moreover, are not limited to those that might be considered to have a 'progressive' dimension. Reflecting the fears and concerns of many observing contemporary European politics, we also widen our scope to consider those alternatives to neoliberalism that appear to be emerging on the right, and which in turn act as potential obstacles that more progressive alternatives must overcome.

The impact of the Brexit vote is, at the time of writing (July 2016), starkly highlighting this need to consider progressive alternatives in the present. Whilst Brexit is different things to different people, it seems clear that at least part of the explanation for the British rejection of European integration lies in a number of factors: its association with a rise in inequality; the negative consequences associated with the single market; the democratic deficit; and the inability to adopt measures that might foster greater social equality. The EU is associated with a period of post-democracy that has seen citizens' capacity to make decisions gradually replaced with that of major transnational corporations (Crouch 2012). Rather than leading in a straightforward manner to greater demands for social equality, however, the Brexit vote also highlights the potential for popular disaffection in the light of austerity and inequality to lead to xenophobia, anti-immigration sentiment and fervent nationalism. Without seeking to deny the racist attitudes and prejudices that come with having a colonial past (Bhambra 2016), Brexit also highlights the impact of widening socio-economic inequality in terms of its capacity for fostering and encouraging such ideas to germinate or regain ground. It is in this context that the need to consider more progressive alternatives, and how they might be achieved, is all the more urgent.

The contributions to this special issue are not, however, in agreement. Perhaps the key point of contention between the contributors relates to what appears to be a divide between hope and despair. While some contributions are more optimistic about the prospects for change and the viability of those alternatives that are being pursued in the present (Scholl and Freyberg-Inan, Arampatzi, Wigger, Bailey et al., Cillo and Pradella), others highlight either the greater potential for more worrying alternatives to come to fruition (Worth) or otherwise highlight the scale of the obstacles that need to be overcome (della Porta and Parks). Likewise, the focus of our contributors range from those who see alternatives pursued by political parties in particular as key to the possibilities for change (Worth), those who search for opportunities within the supranational 
institutions of the European Union (della Porta and Parks), and those who are more interested in what are sometimes termed extra-parliamentary movements, both national (Arampatzi, Wigger, Bailey et al) and transnational (Scholl and Freyberg-Inan). Of course, the national and the transnational also intersect, creating the possibility that transnational connections open opportunities at the national level (Cillo and Pradella), and indeed the opposite also seems possible. The special issue therefore makes an important comparative contribution to the study of austerity-era alternatives.

In seeking to understand the possibility for change in the present, we need also to consider the agents that might be responsible for creating the pressures that would bring about that change. In their contribution, Bailey et al (this volume) argue that the post-2008 context has prompted the emergence of a novel and sometimes contradictory, pragmatically prefigurative, subjectivity. This disruptive agent, they argue, is responsible for some of the most significantly disruptive events in the face of a concerted attempt to impose austerity upon European society. Prior to the 2008 crisis, the authors claim, four ideal types of disruptive actors can be identified: the disengaged, disaffected and disinterested political (non)-actor; the vocal agent of political equality; the refusal-prone materialist; and the prefigurative radical. The authors argue that the financial crisis has stymied the disruptive methods of each of the first three of these, in various ways: simple disengagement has become difficult with a rise in punitive state tactics; calls for political equality have been met with the closure of channels through which their voice might be heard in a context of declining state responsiveness; and refusal-prone materialists have found both the firm and the state increasingly unresponsive to standard forms of labour organisation. Combinations between each of these three forms of subjectivity, with the final category - prefigurative radicalism - have thus abounded in the wake of the crisis. This is illustrated with examples from the very different contexts of Spain and the UK. The resulting hybrid forms of disruption - a pragmatically prefigurative form of disruptive subjectivity has been responsible for some of the more unusual events witnessed since 2010, including the election of Jeremy Corbyn as Labour Party leader, and Ada Colau as Mayor of Barcelona, both with the support of an electorate apparently associated with extra/anti-parliamentary principles of horizontalism that would at first sight appear to reject the parliamentary route to power. Similar forms of disruptive agency are also observed in a number of the other pieces included in this issue.

The adoption of prefigurative principles can also be seen in a number of the alternatives considered by the other authors. In her contribution, focusing on Spain and especially Catalonia, Wigger details the emergence of a 'solidarity economy', developing alongside the more 'visible' forms of protest that have erupted in response to the austerity measures associated with the post-2008 crisis period. Participants in this solidarity economy have sought to produce alternative communities and cooperatives that are able in turn to pose substantive and concrete alternatives to austerity. This is despite the fact that the initiatives themselves do not posit themselves as being in direct confrontation with the firms and states advancing an austerity agenda. Indeed, it is the austerity context in which 'circuits of collectivized economy networks' have the potential to flourish as alternatives to the capitalist context within which they are developing. As Wigger puts it, the formation of these alternative social relations represent transformative agency beyond expressions of dissent and protest that is not merely reactive or defensive but that involves an actual material reorganisation of social relations in everyday life' (Wigger, this volume).

Similar observations can be found in the article by Arampatzi on Greece during the crisis. In this case, however, solidarity initiatives have emerged in direct response to the austerity that was so central to the crisis in Greece. Arampatzi's article draws on ethnographic research in Athens to highlight the work of two local groups in the city centre neighbourhood of Exarcheia - the Resident committee and their Time bank project, and the Solidarity network of Exarcheia. Here we find solidarity as 'narrated, 
imagined and practiced' in response to and in a context of austerity and precarity. As Arampatzi shows, more than $\mathbf{4 0 0}$ groups in Greece have formed a wide and dense network of solidarity initiatives. These seek to find alternative ways in which the most urgent requirements for social reproduction can be met, including food, clothing, healthcare, and housing. These have also prompted experiments with alternative economies, with the allocation of resources through time banks posing an alternative to allocation through money and the market. These initiatives have created alternative avenues through which the principles of mutual aid and solidarity have been allowed to operate, prompting in turn further experiments with additional types of social cooperation.

In terms of opportunities for new modes of cooperation, Cillo and Pradella turn their attention to more direct relations of production (and transnational production), focusing especially on the disruptive capacity of immigrant workers as the main organisers of struggles in the Italian logistics sector. While the past two decades have wrought considerable change in the sphere of capitalist production, the authors find that new, different spaces for labour contestation have also been able to develop. They show how the spread of 'just in time' production has acted both to impose conditions of precarity upon those employed by firms adopting those practices, but also in many ways to create opportunities for disruption by those same workers. As this method of production relies heavily on integrated supply chains, disrupting a single link in the chain can have wide-ranging effects across sectors and borders. Where workers are able to overcome the considerable constraints posed by (among other things) the casualization of labour, opportunities for contestation are created by the sensitivity that 'just in time' production has to any form of disruption.

In their contribution to the special issue, della Porta and Parks explore the possibility for alternatives to develop within the institutions of the European Union. As the authors show, one of the key developments that has emerged in terms of the political opportunity structure presented by the European Union, is that of a closing down of opportunities at the EU-level, especially with regard to alternatives to neoliberalism, which has been further entrenched within the institutional infrastructure of the EU. As such, whilst in formal terms the EU has opened up a number of channels through which grassroots initiatives might promote alternatives within the institutions of the European Union, the political climate has become such that this is often viewed as undesirable by the EU's political elites, and/or inhospitable by those undertaking grassroots campaigns (who have therefore tended to focus much more on national-level targets as a more indirect means by which to influence EU decisions). Parks and della Porta focus especially on the Lisbon Treaty's introduction of the European Parliament's right to veto international trade agreements, as well as the new European Citizens' Initiative.

Also adopting a transnational focus, but this time outside of the formal EU institutions, Scholl and Freyberg-Inan look at calls for alternatives to austerity posed directly to the EU level, focusing on Blockupy and the Alter Summit platform. In a neo-Gramscian view, effective and broad alliances that propose alternatives to austerity are crucial to any challenge to the neoliberal status quo. Coherent and resonant master frames are in turn crucial to the construction of such alliances. Through an analysis of the discourses of Blockupy and the Alter Summit platform, the authors show that an antiausterity master frame is emerging through the conscious alignment of three elements by movement actors: the rejection of austerity measures, coordinated transnational solidarity, and the defence of democracy and popular sovereignty. The resulting master frame is seen as having the potential to bridge the work of a variety of movements, though challenges are present in the form of the need to agree on transnational alternatives to austerity and disagreement over whether the EU can be reformed or should rather be abandoned. 
Finally, Worth extends the focus of the special issue to consider the scope for both left and right ideas to become hegemonic, specifically as alternatives to neoliberalism. As his article reminds us, moreover, the notion of alternatives is not limited to those who seek to end neoliberalism. Indeed, through his careful Gramscian analysis of the different social forces currently jostling for dominance across Europe, Worth points to the existence of (at least) two currents pushing for neoliberal continuity, as well as (at least) two alternatives to neoliberal continuity - one on the left and one on the right. On the left, we see alternatives which advocate a rejection of austerity measures, such as those of pre-referendum Syriza and Podemos, as well as the neo-mercantilist alternative emerging in Iceland. This sits alongside what Worth claims is an overly disjointed collection of protest movements that has failed to form a coherent alternative programme. This is rivalled by a populist, nativist and nationalist far right that opposes neoliberalism, including Jobbik, the True Finns and Golden Dawn.

In a sense, therefore, the contributions to this special issue are not united in their assessment of either the possibility for (desirable) alternatives to flourish, nor are they in agreement on where we might look to for those alternatives to come into existence. Rather than advocate a single avenue for change it might be more accurate to say that the contributions to the special issue question the degree to which the contemporary context provides hope as sought-after alternatives become potentialities, and maybe even flourish, or whether instead we might be right to fear an impending failure (and roll our sleeves up to work to overcome the obstacles that are theorised). Where the papers are perhaps united, however, is in their hope that we might be right to hope, rather than to only find reasons for despair. We hope that the special issue can, at least, contribute towards that goal.

\section{Acknowledgements}

The collaborations that led to this special issue were facilitated by an ESRC seminar series grant, Understanding the Post-Crisis Landscape: Assessing Change in Economic Management, Welfare, Work and Democracy. We are especially grateful to the anonymous reviewers, who spent a considerable amount of time providing detailed and helpful comments that made a significant contribution to the final version of the special issue.

\section{References}

Bhambra, G., 2016, 'Viewpoint: Brexit, Class And British 'National' Identity', Discover Society 5 July 2016. Available: http://discoversociety.org/2016/07/05/viewpoint-brexit-class-and-british-nationalidentity/

Blyth, M., 2013, Austerity: The History of a Dangerous Idea (Oxford, Oxford University Press).

Ferrera, M. (2008) 'The European Welfare State: Golden Achievements, Silver Prospects', West European Politics, 31, 82-107.

Harvey, D. 2005. A Brief History of Neoliberalism. Oxford: Oxford University Press.

Huke, N., Clua-Losada, M. and Bailey, D.J. (2015) 'Disrupting the European Crisis: a Critical Political Economy of Contestation, Subversion and Escape', New Political Economy, 20(5): 725-51.

Konzelmann, S.J. 2014. The political economics of austerity. Cambridge Journal of Economics 38(4): 701-41.

Lonkila, M., forthcoming, 'Social Network Sites and Political Governance in Russia', in V. Gel'man (ed.), Authoritarian Modernization in Russia: Ideas, Institutions and Policies (London: Routledge). 
Peck, J., Theodore, N. and Brenner, N. 2012. Neoliberalism Resurgent? Market Rule after the Great Recession. The South Altlantic Quarterly 111(2): 265-88.

Scott, J.C., 1990, Domination and the Arts of Resistance: Hidden Transcripts. Yale University Press.

Stanley, L. (2014), “We're Reaping What We Sowed': Everyday Crisis Narratives and Acquiescence to the Age of Austerity', New Political Economy, 19 (6), pp. 895-917.

Wacquant, L. 2010. Crafting the Neoliberal State: Workfare, Prisonfare, and Social Insecurity.

Sociological Forum 25(2): 197-220.

Wigger, A. (2016) "Anarchism as emancipatory theory and praxis: Implications for critical Marxist research" Capital \& Class 40 (1): 129-145. 